\begin{tabular}{|c|l|}
\hline Title & $\begin{array}{l}\text { Effects of Water Polluted by Oil on A quatic A nimals : III. Pretreatment in detection of n-paraffins in marine sediments } \\
\text { by gas chromatography }\end{array}$ \\
\hline Author(s) & MOTOHIRO, Terushige; ISEYA, ZENSUKE \\
\hline Citation & 北海道大學水産學部研究彙報, 26(4), 372-380 \\
\hline Issue Date & 1976-03 \\
\hline Doc URL & http://hdl.handle.net/2115/23576 \\
\hline Type & bulletin (article) \\
\hline File Information & 26(4)_P372-380.pdf \\
\hline
\end{tabular}

Instructions for use 
Bull. Fac. Fish. Hokkaido Univ.

26(4), 372-382. 1976

\title{
Effects of Water Polluted by Oil on Aquatic Animals \\ III. Pretreatment in detection of $n$-paraffins in marine sediments by gas chromatography
}

\author{
Terushige Motohiro* and Zensuke IseyA*
}

\begin{abstract}
Preliminary treatments by column and thin layer chromatographies were examined using solvents with different polarities, in order to detect $n$-paráffins in marine sediments by GC analysis. Petroleum ether + benzene $=90: 10(\mathrm{v} / \mathrm{v})$ for column chromatography and $n$-hexane + benzene $=95: 5(\nabla / v)$ for TLC were more effective than other tested solvents to separate n-paraffins from contaminants. With pretreatment, n-paraffins below $\mathrm{C}_{13}$ tends to disappear due to evaporation losses.
\end{abstract}

Distillation and wax content determinations can be used to differentiate between fuel oil, crude oil, and tank bottom residues at the time of discharge ${ }^{3}$. However, gas-liquid chromatography (GC) has been adapted for the detection of oils in polluted marine environments(1)3)4), because after the oil has weathered at sea, collected samples have suffered evaporation losses and may contain as much as $80 \%$ of water together with large amounts of solid matter ${ }^{3)}$ which make it impossible to analyse by distillation and wax determinations. Thus, the oils collected from polluted waters are often analysed by GC without any preliminary treatment ${ }^{133}$, while those from the beaches, marine sediments and aquatic animals are purified prior to analysing by $\mathrm{GC}^{4}$ ). However, indistinct chromatograms are given with the samples obtained by steam distillation or by direct heating of spilt oil at sea ${ }^{4}$.

Methanol and methanol $+25 \%$ benzene ${ }^{5) 6}$, chloroform: methanol $=2: 1(v / v)$, n-pentane $e^{7}$ and isopentane $e^{8)}$ have been used as solvent for extraction of lipid material. The lipid material can be separated from hydrocarbons by column chromatography. Silica gel $+5 \% \mathrm{H}_{2} \mathrm{O}$ : alumina $+6 \% \quad \mathrm{H}_{2} \mathrm{O}=2: 1^{5) 6}$ ) and silicic acid ${ }^{49) 10)}$ are the absorbents. The hydrocarbon fraction elutes with hexane ${ }^{9)}$, n-pentane+benzene $=1: 1^{5}$ ), chloroform ${ }^{4}$, hexane + benzene $=95: 5^{11}$ ) and petroleum ether + benzene $=9: 1^{12}$ ).

The hydrocarbon fraction is purified by thin layer chromatography (TLC). The TLC plate is developed with iso-octane ${ }^{5)}$ and $n$-hexane+benzene $=95: 5^{11}$ ).

The present paper reports on the pretreatment of marine sediments with suitable solvents to detect $n$-paraffins by gas chromatography.

* Training Factory of Food Engineering, Faculty of Fisheries, Hokkaido University (北海道大学水産学部食品製造実習工場)

$$
-372-
$$


Мотонгro \& Istya: Oil pollution-III. Detection of n-parafins in marine sediments

\section{Experimental}

\section{Materials}

The sample of marine sediments was collected by a diver from the Hakodate Harbour in water depth 8 meters. This area is now developing oil contamination because of large amounts of effluent from the city. The sediments were frozen at $-20^{\circ} \mathrm{C}$ until required. A $100 \mathrm{~g}$ of the thawed sediments was weighed.

Iranian crude oil and pure n-paraffins were used as the control sample.

\section{Analytical procedures}

\section{Lipid extraction}

The sediments were extracted with 3 times their volume of chloroform + methanol=2:14) for 12 hours. This procedure was repeated four times. The combined extracts were washed with water to remove methanol, left for 24 hours, dried with anhydrous sodium sulphate, and evaporated at room temperature in a rotary evaporator.

\section{Column chromatography}

The residue after evaporation was dissolved in $n$-hexane and transferred to a column $300 \times 15 \mathrm{~mm}$ id. The column had been packed in n-hexane with $10 \mathrm{~g}$ of activated silica gel (Davison No. 922, 100-200 meshes). It was then developed with the following solvents;

i) n-Hexane + benzene $\left.=95: 5(\mathrm{v} / \mathrm{v})^{10}\right)$

ii) Petroleum ether+benzene $=90: 10(\mathrm{v} / \mathrm{v})^{11)}$

iii) $\mathrm{n}$-Hexane + benzene $=50: 50(\mathrm{v} / \mathrm{v})^{10)}$

iv) Chloroform4)

This procedure separates the lipid material from the hydrocarbons. The eluate was distilled under reduced pressure at room temperature.

\section{Thin layer chromatography}

The residue after distillation was dissolved in a minimum amount of chloroform and $200 \mu \mathrm{l}$ of the solution was transferred to activated $\left(105^{\circ} \mathrm{C}, 30 \mathrm{mins}\right)$ silica gel with a micro-pipette. TLC-plates (precoated TLC-sheets, silica gel B-O with $0.5 \mathrm{~mm}$ thick on glass plate, Wako Chem. Ind. Ltd.) were developed with the following solvents:

i) $\mathrm{n}$-Hexane + benzene $\left.=95: 5(\mathrm{v} / \mathrm{v})^{10}\right)$

ii) $\mathrm{n}$-Hexane + benzene $\left.=50: 50(\mathrm{v} / \mathrm{v})^{10}\right)$

After development by spraying with $3 \%$ phosphomolybdic acid solution, the fastest-moving fraction which contains the saturated n-paraffins, was cut from the plate. The solid support was scraped off the glass plate and extracted with chloroform $^{4}$, because of the lower boiling point and higher dissolution effect compared with other solvents. 


\section{GG analysis}

An aliquot of the extract was applied to a $200 \mathrm{~cm} \times 3 \mathrm{~mm}$ id. stainless-steel column packed with chromosorb WAW DMCS (60-80 mesh) coated with $1.5 \%$ silicon SE-30. The column was temperature programmed from $80^{\circ}$ to $240^{\circ}$ at $5^{\circ} \mathrm{C} / \mathrm{min}$. The carrier gas (nitrogen) flow rate was $30 \mathrm{ml} / \mathrm{min}$, and detection of n-paraffin constituents was made by Hitachi Type 063 flame ionisation detector. n-Paraffin peaks on the chromatogram from $\mathrm{C}_{12}$ to $\mathrm{C}_{24}$ were identified with standard pure reagents (Wako Pure Chem. Ind. Ltd.).

\section{Results and discussion}

In all photographs, saturated paraffins $\left(\mathrm{C}_{12}-\mathrm{C}_{24}\right)$ were contained in the fastest-moving fraction $(\mathrm{Rf}=1.0)$ and unsaturated paraffins and aromatic hydrocarbons were contained in the slower-moving fractions $(\mathrm{Rf}=0.7-0.8)$ on TLC plates. (Figs. 1-3).

It appears that petroleum ether+benzene $=90: 10(\mathrm{v} / \mathrm{v})$ is the most effective among the tested solvents for separating hydrocarbons both from the marine sediments and the Iranian crude oil by column chromatography (Figs. 1-2 and $3-1)$.

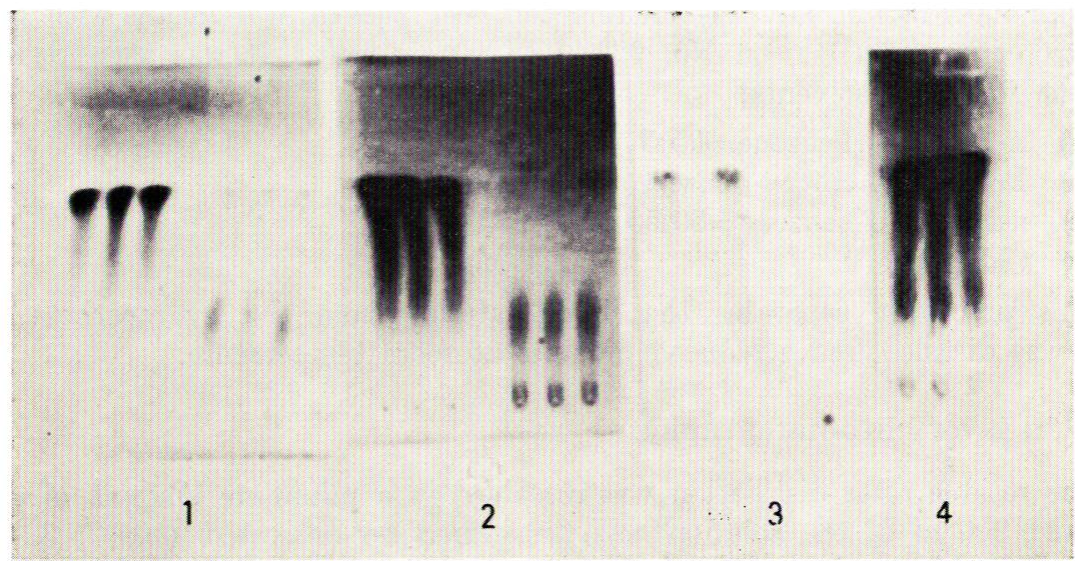

Fig. 1. TLC patterns of hydrocarbon in marine sediments by developing with n-hexane+ benzene $=95: 5(\mathrm{v} / \mathrm{v})$.

1. Hydrocarbons separated by CC with $\mathrm{n}$-hexane + benzene $=95: 5$ (v/v) (left 3 runs). Hydrocarbons separated by CC with $\mathrm{n}$-hexane+benzene $=50: 50(\mathrm{v} / \mathrm{v})$ after intial separation with $\mathrm{n}$-hexane+benzene $=95: 5(\mathrm{v} / \mathrm{v})$ (right $3 \mathrm{runs}$ ).

2. Hydrocarbons separated by CC with petroleum ether + benzene $=90: 10(\mathrm{v} / \mathrm{v})(\mathrm{left}$ 3 runs). Hydrocarbons separated by CC with $n$-hexane + benzene $=50: 50(\mathrm{v} / \mathrm{v})$ after initial separation with petroleum ether + benzene $=90: 10(\mathrm{v} / \mathrm{v})$ (right 3 runs).

3. Hydrocarbons separated by CC with $\mathrm{n}$-hexane + benzene $=50: 50$ (v/v) (left 2 runs). Hydrocarbons separated by CC with chloroform after initial separation with n-hexane + benzene $=50: 50(\mathrm{v} / \mathrm{v})$ (right 1 runs).

4. Hydrocarbons separated by CC with chloroform (3 runs). 
Мотонiro \& Iseya: Oil Pollution-III. Detection of n-paraffins in marine sediments

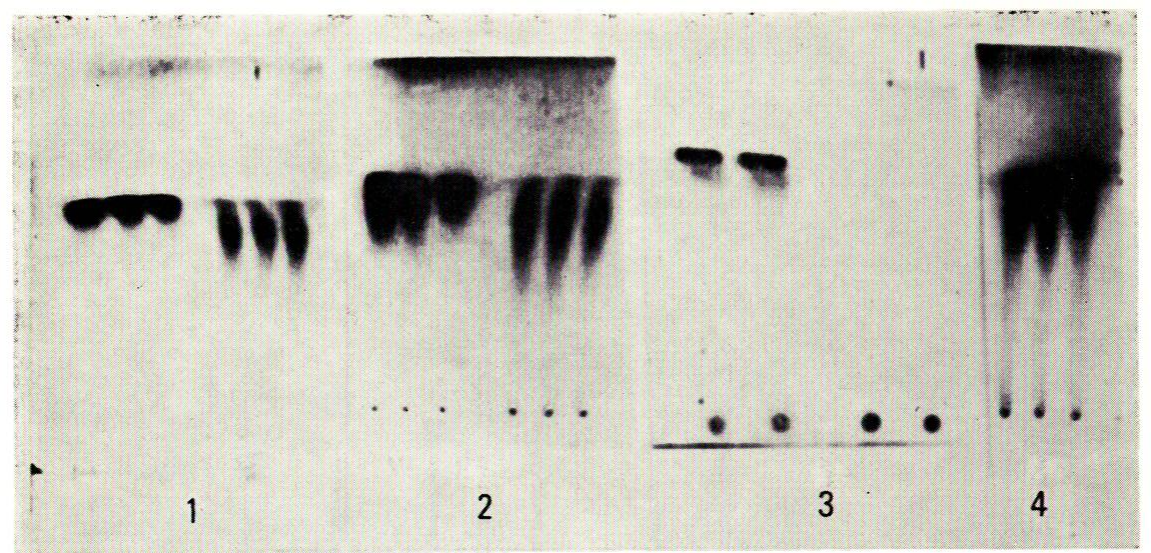

Fig. 2. TLC patterns of hydrocarbons in marine sediments by developing with n-hexane + benzene $=50: 50(\mathrm{v} / \mathrm{v})$.

1. Hydrocarbons treated with similar way described in Fig. 1-1. (each 3 runs of left and right).

2. Hydrocarbons treated with similar way described in Fig. 1-2. (each 3 runs of left and right).

3. Hydrocarbons treated with similar way described in Fig. 1-3. (each 2 runs of left and right).

4. Hydrocarbons treated with similar way described in Fig. 1-4. (3 runs).

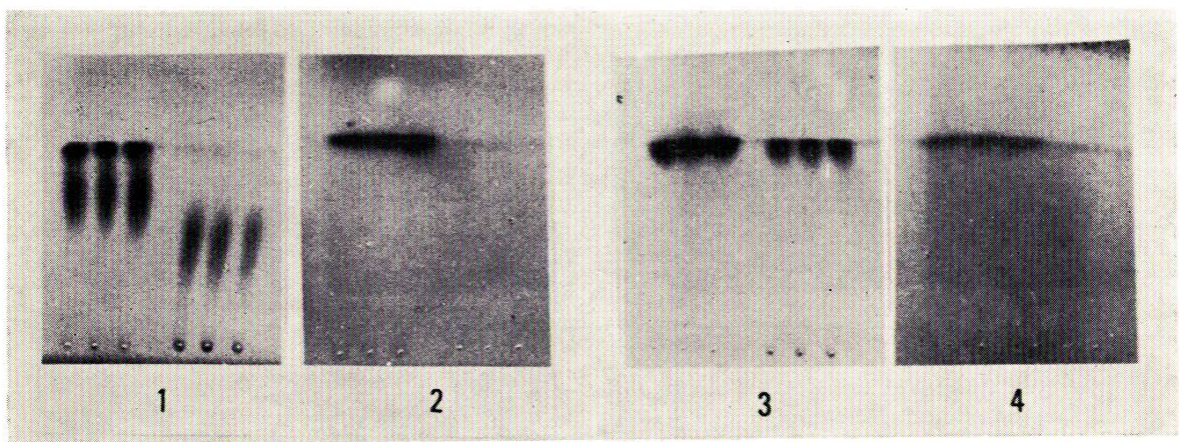

Fig. 3. TLC patterns of hydrocarbons in Iranian crude oil and n-paraffins.

1. Iranian crude oil. Hydrocarbons separated by CC with petroleum ether+benzene $=90: 10(\mathrm{v} / \mathrm{v})$ and developed with $\mathrm{n}$-hexane+benzene $=95: 5(\mathrm{v} / \mathrm{v})$ on TLC. (3 runs left). Hydrocarbons separated by $\mathrm{CC}$ with $\mathrm{n}$-hexane+benzene $=50: 50(\mathrm{v} / \mathrm{v})$ after initial separation with petroleum ether + benzene $=90: 10(\mathrm{v} / \mathrm{v})$ and developed with $\mathrm{n}$-hexane + benzene $=95: 5(\mathrm{v} / \mathrm{v})$ on TLC. ( 3 runs right).

2. n-Paraffins. Hydrocarbons treated with similar way described above. (each 3 runs of left and right).

3. Iranian crude oil. Hydrocarbons separated by CC with petroleum ether + benzene $=90: 10(\mathrm{v} / \mathrm{v})$ and developed with $\mathrm{n}$-hexane + benzene $=50: 50(\mathrm{v} / \mathrm{v})$ on TLC. (3 runs left). Hydrocarbons separated by CC with $\mathrm{n}$-hexane+benzene=50:50 (v/v) after initial separation with petroleum ether + benzene $=90: 10(\mathrm{v} / \mathrm{v})$ and developed with $\mathrm{n}$-hexane + benzene $=50: 50(\mathrm{v} / \mathrm{v})$ on TLC. (3 runs right).

4. n-Paraffins. Hydrocarbons treated with similar way described above. (each 3 runs of left and right). 
Bull. Fac. Fish. Hokkaido Univ. 26(4), 1975.

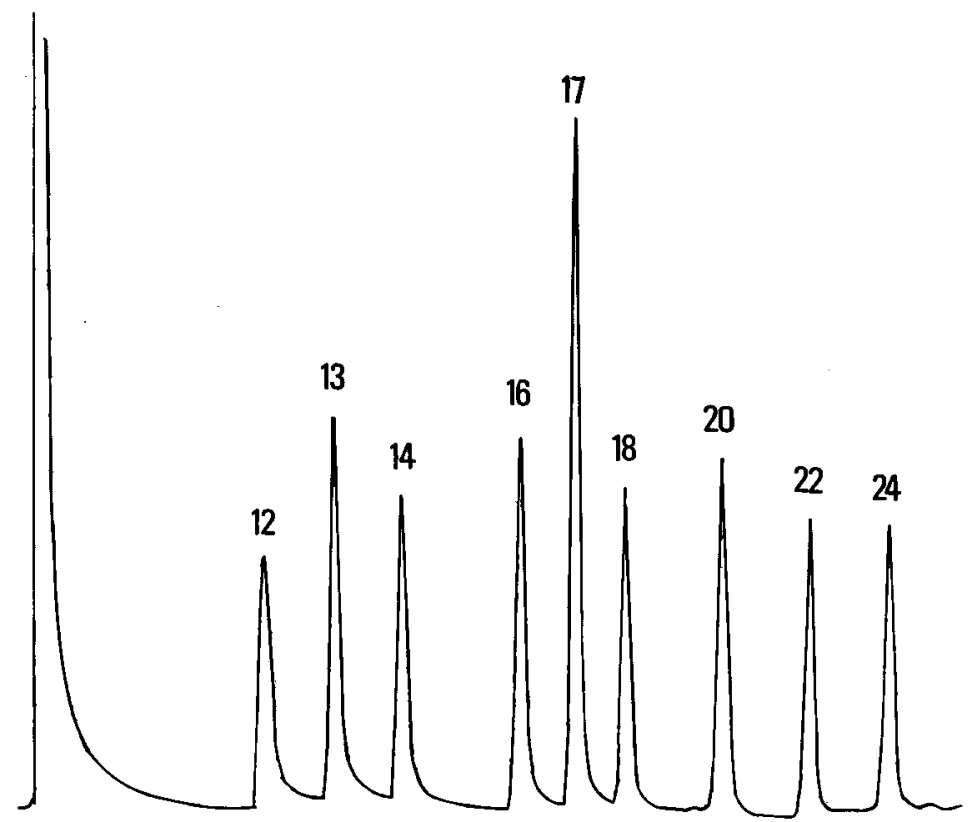

Fig. 4. $\mathrm{GC}$ peaks of n-paraffins from $\mathrm{C}_{12}$ to $\mathrm{C}_{24}$ without pretreatments.

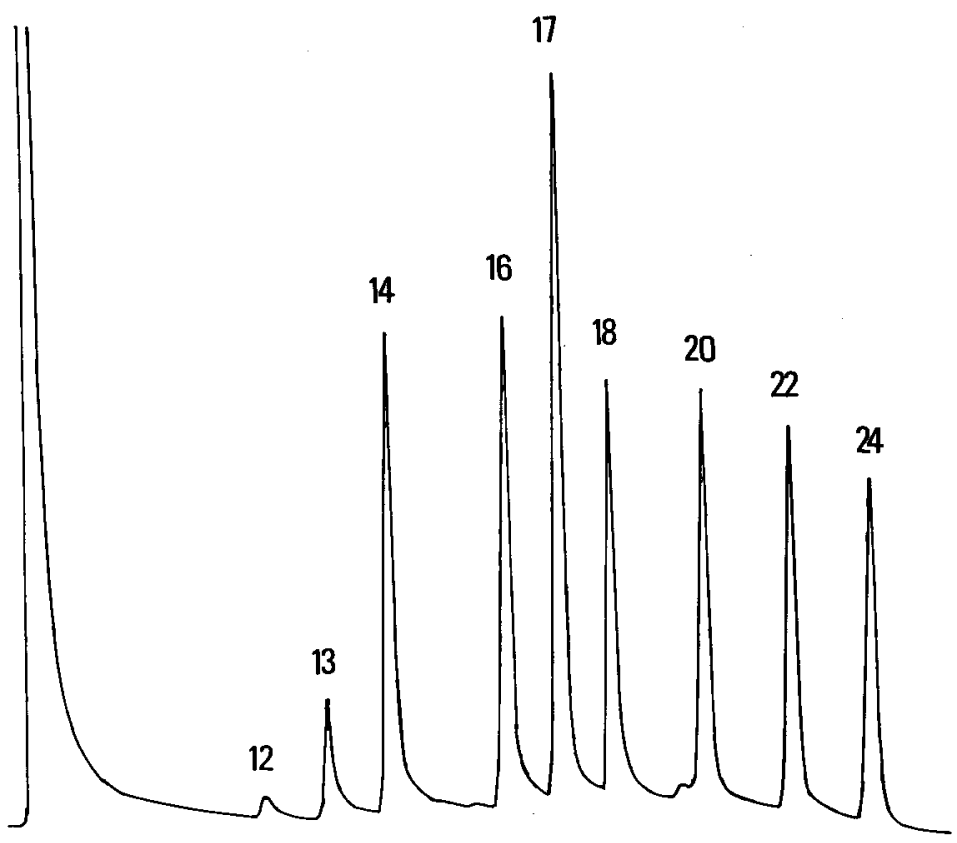

Fig. 5. GC peaks of n-paraffins from $\mathrm{C}_{12}$ to $\mathrm{C}_{24}$ with pretreatments. (Petroleum ether + benzene $=90: 10(\mathrm{v} / \mathrm{v})$ for $\mathrm{CC}$ and $\mathrm{n}$-hexane+benzene $=95: 5(\mathrm{v} / \mathrm{v})$ for TLC). 
Motohiro \& Istry : Oil Pollution-III. Detection of n-paraffins in marine sediments

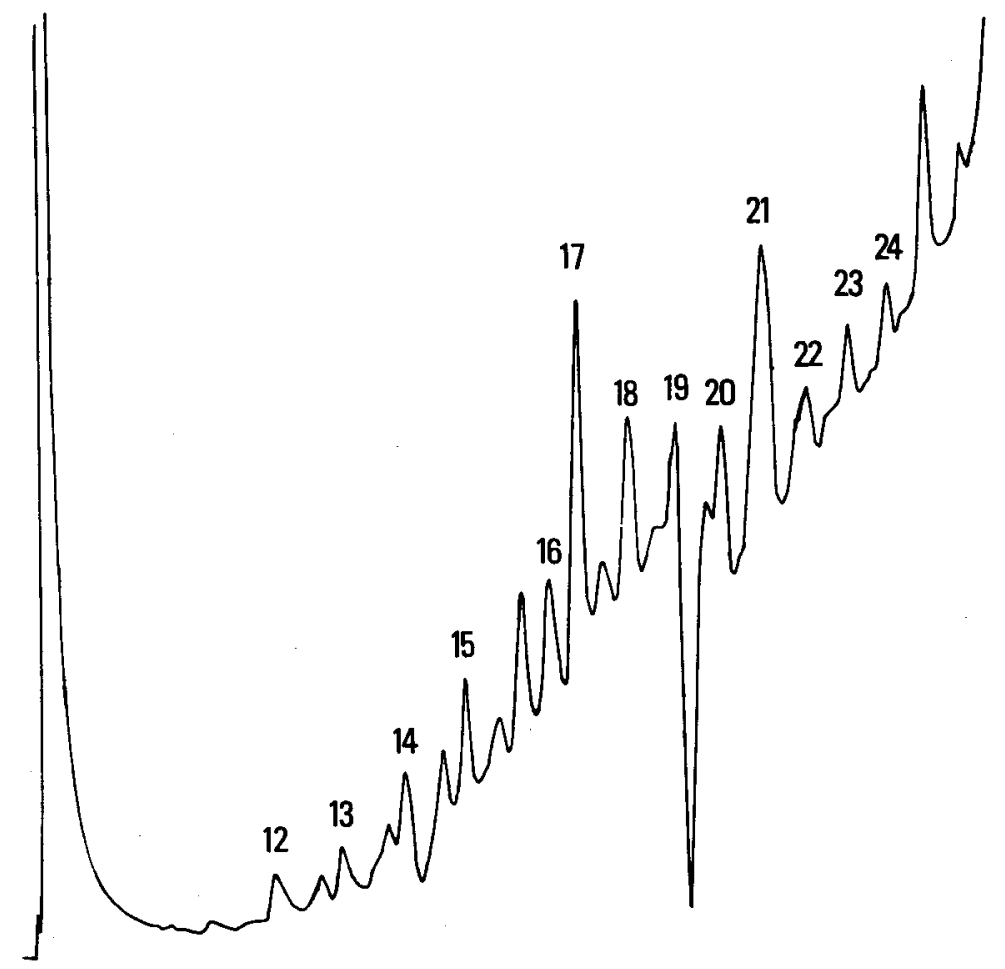

Fig. 6. GC patterns of $\mathrm{n}$-paraffins in marine sediments with pretreatments. (Petroleum ether + benzene $=90: 10(v / v)$ for CC and $n$-hexane + benzene $=95: 5(v / v)$ for TLC).

The eluates with chloroform through the column contained not only paraffins and aromatic hydrocarbons, but also included many other contaminants which were developed near the starting point on TLC plates (Fig. 1-4). n-Paraffins still remained in the eluates on $n$-hexane-benzene $=95: 5(\mathrm{v} / \mathrm{v})$ which was applied successively to the column (Fig. 1-1). These facts suggests that the intensity of the elution of $n$-paraffins depends on the polarity of the solvent.

Development could be effected with $n$-hexane-benzene $=95: 5(\mathrm{v} / \mathrm{v})$, separating $n$-paraffins from aromatic hydrocarbons on the TLC plate, while it was difficult to separate them with $n$-hexane+benzene $=50: 50(\mathrm{v} / \mathrm{v})$ because both hydrocarbons were found in the fastest-moving fraction (Figs. 1, 2, and 3).

The GC patterns differed in their response to the fastest-moving fractions cut from the TLC plates. In comparison with n-paraffins below $\mathrm{C}_{13}$ with and without pretreatments, the GC peaks of the former were smaller than those of evaporation losses of lower molecular weight hydrocarbons with the pretreatment (Figs. 4 and 5).

Significant peaks were obtained in the GC patterns of n-paraffins in marine sediments treated with petroleum ether + benzene $=90: 10(\mathrm{v} / \mathrm{v})$ and with $\mathrm{n}$-hexane + 
Bull. Fac. Fish. Hokkaido Univ. 26(4), 19751

Fig. 7. GC patterns of $n$-paraffins in marine sediments with pretreatments. (Chloroform for $\mathrm{CC}$ and $\mathrm{n}$-hexane+benzene $=95: 5(\mathrm{v} / \mathrm{v})$ for TLC).

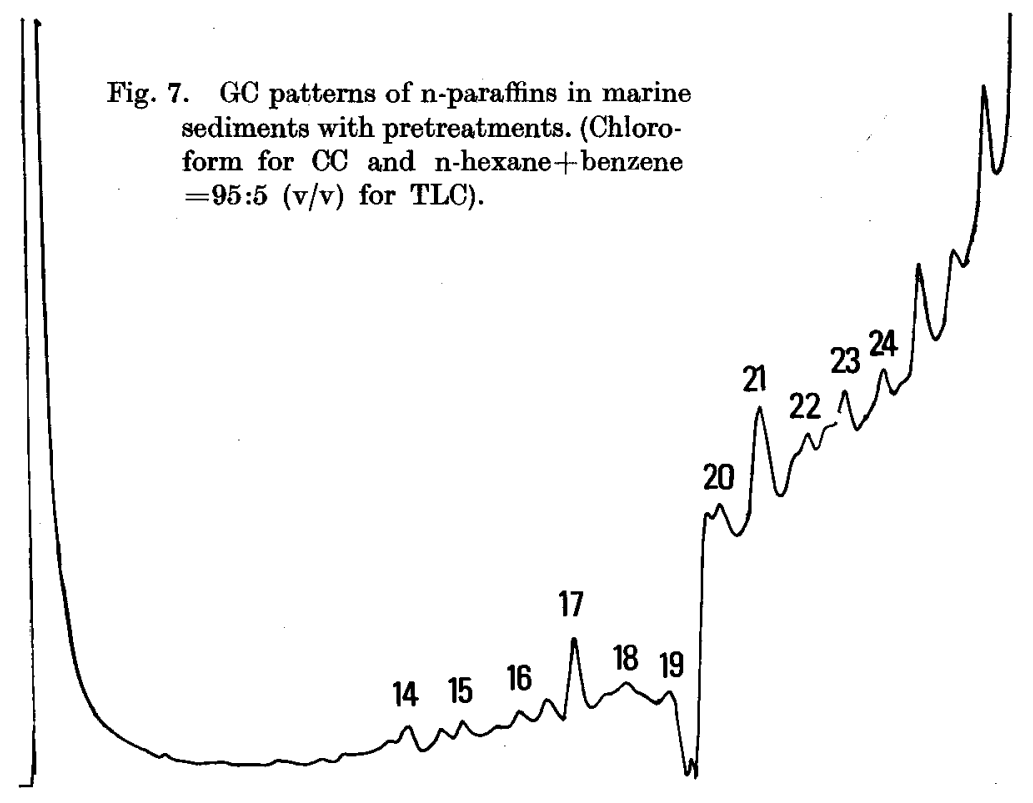

Fig. 8. GC patterns of n-paraffins in marine sediments with pretreatments. (n-hexane + benzene= $50: 50(v / v)$ for CC and $n$-hexane + benzene $=95: 5(\mathrm{v} / \mathrm{v})$ for TLC).

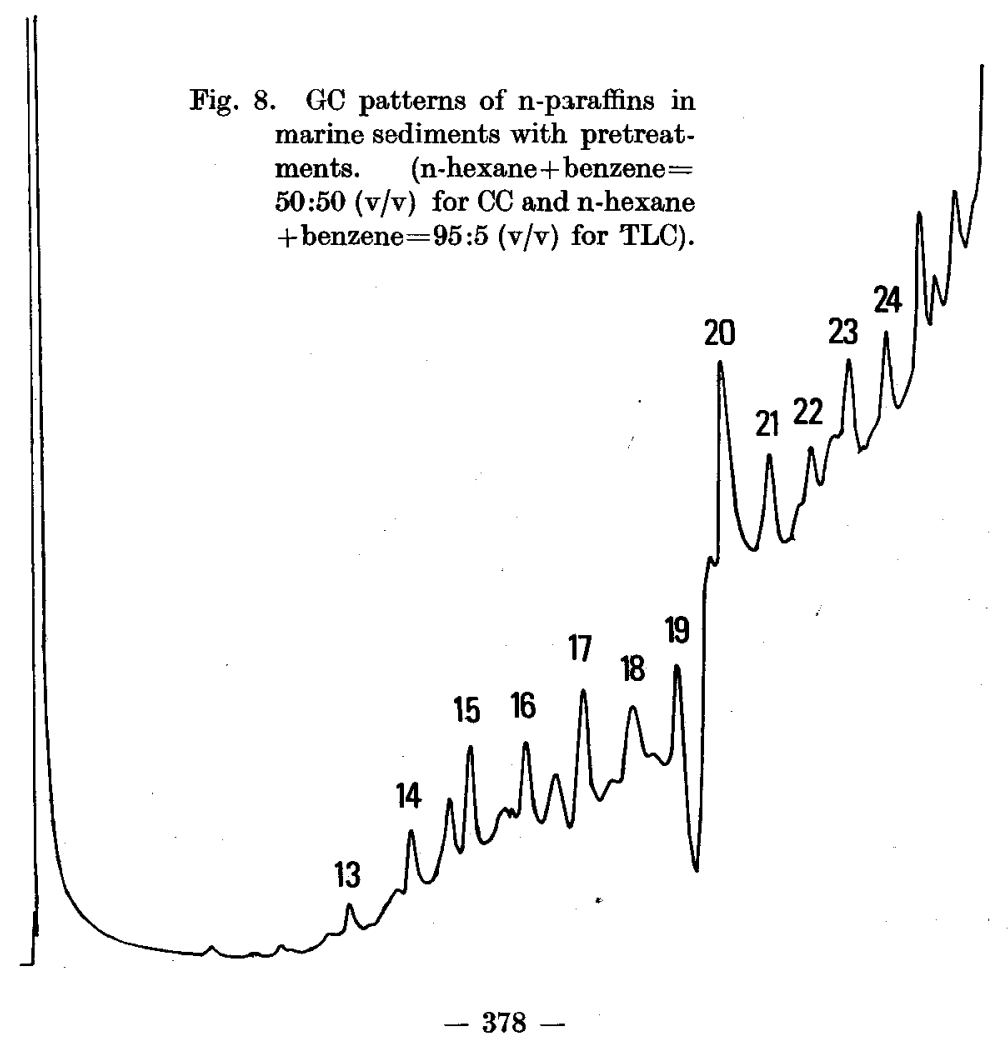


Moтoнiro \& Iseya : Oil Pollution-III. Detection of n-paraffins in marine sediments

Fig. 9. GC patterns of $n$-paraffins in marine sediments with pretreatments. (n-hexane+benzene $=$ $95: 5(v / v)$ for $\mathrm{CC}$ and $n$-hexane +benzene $=95: 5(v / v)$ for TLC).

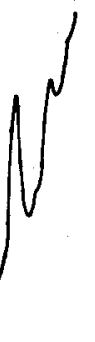

17

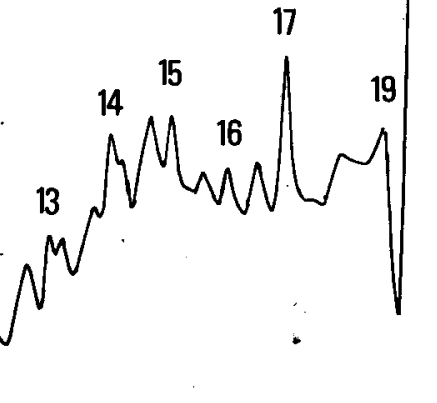

Fig. 10. GC patterns of n-paraffins in marine sediments with pretreatments. (Petroleum ether + benzene $=90: 10(\mathrm{v} / \mathrm{v})$ for $\mathrm{CC}$ and $\mathrm{n}$-hexane +benzene $=50: 50(\mathrm{v} / \mathrm{v})$ for $\mathrm{TLC})$.

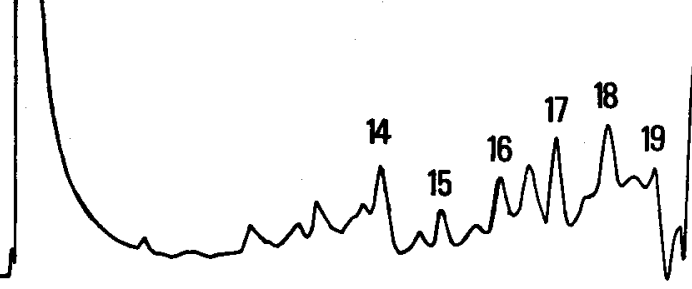


Bull. Fac. Fish. Hokkaido Univ. 26(4), 1975.

benzene $=95: 5(\mathrm{v} / \mathrm{v})$ as the developing solvents in column chromatography and in TLC, respectively (Fig. 6). All of the samples treated with chloroform, $n$-hexane+ benzene $=50: 50(\mathrm{v} / \mathrm{v})$ and $n$-hexane + benzene $=95: 5(\mathrm{v} / \mathrm{v})$ gave lower peaks of $n$ paraffins than those seen in Fig. 6. (Figs. 7, 8 and 9), and particularly that treated with chloroform contained contaminants to some extent which inhibited analysis by GC. Using petroleum ether+benzene $=90: 10(\mathrm{v} / \mathrm{v})$ as initial solvent for the column chromatography, and $\mathrm{n}$-hexane+benzene $=50: 50(\mathrm{v} / \mathrm{v})$ as subsequent solvent for the TLC, the n-paraffins fraction on TLC plate had been contaminated with aromatic hydrocarbons which resulted in a raising of the base line of the chromatograms in GC (Fig. 10).

A significant level of hydrocarbons might be calculated from each peak on the chromatogram of $n$-paraffins above $C_{14}$ with the exception of those below $C_{13}$. Further study is being undertaken in this respect.

The authors are indebted to Dr. R.M. Love of the Torry Research Station, Aberdeen, Scotland, for kindly reading the manuscript.

\section{References}

1) Ehrhardt, M. and Blumer, M. (1972). The source identification of marine hydrocarbons by gas chromatography. Environ. pollut. 5, 179-194.

2) Garza, M.E. and Muth, J. (1974). Characterization of crude, semi-refined and refined oils by gas-liquid chromatography. Environ. Sci. Technol. 8, 249-255.

3) Ramsdale, S.J., and Wilkinson, R.E. (1968). Scientific aspects of pollution of the sea by oil. 68p. Elsevier Publ. Co. Ltd., London.

4) Motohiro, T. and Inoue, N. (1973). n-Paraffins in polluted fish by crude oil from "Julliana" wreck. Bull. Fac. Fish., Hokkaido Univ. 23, 204-208.

5) Ehrhardt, M. (1972). Petroleum hydrocarbons in oysters from Galveston Bay. Environ. pollut. 5, 257-271.

6) Clark, Jr. R.C., Finley, J.S. and Gibson, G.G. (1974). Acute effects of outboard motor effluent on two marine shellfish. Environ. Sci. Technol. 8, 1009-1014.

7) Giger, W., Reinhard, M., Schaffner, C. and Stumm, W. (1974). Petroleumderived and indigenous hydrocarbons in recent sediments of Lake Zug, Switzerland. Ibid., 8, 454-455.

8) Shipton, J., Last, J.H., Murry, K.E. and Vale, G.L. (1970). Studies on a kerosinelike taint in mullet (Mugil cephalus). II. Chemical nature of the volatile constituents. J. Sci. Fd. Agric. 21, 433-436.

9) Mackie, P.R., McGill, A.S., and Hardy, R. (1972). Diesel oil contamination of brown trout (Salmo trutta L.). Environ. pollut. 5, 9-16.

10) Zajic, J.E., Supplisson, B. and Volesky, B. (1974). Bacterial degradation and emulsification of No. 6 fuel oil. Environ. Sci. Technol. 8, 664-668.

11) Harada, M. (1969). Qualitative and quantitative determinations of liquid paraffins in food. Shokuhin-Eisei-Kenkyu, 19, 99-104. (In Japanese).

12) Hayashi, N. and Inoue, S. (1969). Analysis of natural soils. I. Separation analysis of human skin lipids extracted from soiled undershirts. Oil Chemistry. 18, 176-183. 